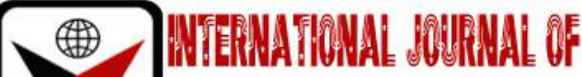

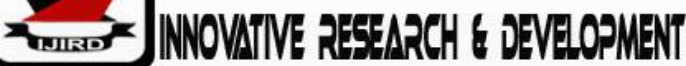

ISSN 2278 - 0211 (Online)

\section{Management of Root-Knot Nematode (Meloidogyne Javanica) with Leaf Powder of Waltheria Indica (Velvet Leaf) on Okra (Abelmoschus Esculentus L)}

\begin{tabular}{c}
\hline Aji Mohammed Bukar \\
Lecturer, Department of Crop Protection, Modibbo Adama University of Technology, Nigeria \\
Umar Ibrahim \\
Professor, Department of Crop Protection, Modibbo Adama University of Technology, Nigeria \\
\hline
\end{tabular}

\begin{abstract}
:
The research was conducted to find out the effect of Waltheria indica (Velvet leaf) on the management of root-knot nematode under screen house condition. Twelve perforated $20 \mathrm{~cm}$ diameter plastic pots containing $4 \mathrm{~kg}$ sterilized loamy soil 50g/pot, 40g/pot, 30g/pot of Waltheria indica powder incorporated into them except the control pot. Okra seed of Wemson spineless were plant into the pots and inoculated with $1000 \mathrm{M}$. javanica juveniles one week after emergence. The results of the experiment showed plant treated with $50 \mathrm{~g} /$ pot recorded the highest mean plant height (32.50cm), number of leaves (10.00), number of fruit (15.00), fruit weight (12.10g). It also recorded the lowest nematode population (81.00) and galling index (2.00). It was then concluded that $W$. indica leaf powder had nematicidal potential. Based on these findings, it is recommended that field studies should be tried under natural condition to ascertain the effectives of plant on $M$. javanica.
\end{abstract}

Keywords: M. javanica, Juveniles, Waltheria indica, Powder

\section{Introduction}

Okra (Albelmoschus esculentus (L.) Moench) is a flowering plant belonging to the family Malvaceae (Mallow family) (NRC, 2006). It is an annual crop grown mainly as a fruit and leafy vegetables in the tropics (Tiamiya et al., 2012). It is an upright plant with a hibiscus-like flower (Smith et al., 2002), grown in tropical and warm temperate climates (Ijewere, 2012). It is widely distributed in the tropical and sub-tropical regions from Africa to Asia, Southern Europe, the Mediterranean countries and the Americans (Andras, et al., 2005). Okra is widely cultivated and can be found in almost every market all over Africa (Schippers, 2000).

Okra is an important constituent of most local dishes in West Africa. It is grown mainly for the leaves and young pods which are frequently eaten as green vegetable. The young immature fruits are important fruit vegetable that are consumed in different form which can be sliced, dehydrated and preserved as dry okra for later use. It is used as a soup thickener and may also be served with rice and other food types (Tiamiyu et al., 2012). Okra contains carbohydrates, protein and vitamin C in large quantities. Others are Iron, Magnesium and Phosphorus with essential and non-essential amino acids which is comparable to that of Soyabean (Adeboye and Oputa, 1996). Farrog et al., (2010) reported that Okra seeds contain greenish-yellow edible oil which is suitable for use as a bio-fuel.

A notable bio-constraint in the production of okra is the plant-parasitic nematode (Saffiudin et al., 2011). Phytonematodes cause loss of yield and quality okra which indirectly reduces as the economic value of the crop (Saffiudin et al., 2011). Root-knot nematode (Meloidogyne species) have been reported as one of the major plant-parasitic nematodes on okra and are responsible for about 70-90\% yield losses (Adesiyan and Akinlade, 1982; Saffiudin et al., 2011).

Root-knot nematodes can be managed effectively chemicals, biological control agents.Addition of organic matter will decrease nematode population in the soil (Walker, 2004). However, use of synthetic chemical develops resistance in the pathogens and have hazardous effect on the environment, there is increasing demand for environment-friendly nematicides with low toxicity and short-term persistence (Vermis and Roberts, 1996). Therefore, alternative management strategies are needed for the control of the phytonematodes. The incorporation of plant parts or extracts into the soil alone or in combination with other biocontrol have been suggested as an alternative, safe and effective control method for the management of phytonematodes (Siddiqui and Alam, 1985). The present study was conducted to manage root-knot nematode Meloidogyne javanica on okra with leave powder of Waltheria indica. 


\section{Materials and Methods}

\subsection{Experimental Site}

The experiment was carried out in the screenhouse of Department of Crop Protection, Modibbo Adama University of Technology, Yola, Nigeria. According to Bashir (2000), Yola lies between latitudes $8^{\circ} \mathrm{N}$ and $11^{`} \mathrm{~N}$ and longitude $11.5^{\circ} \mathrm{E}$ and $13.5^{\circ} \mathrm{E}$ and at an altitude of $185.9 \mathrm{~m}$ above sea level.

\subsection{Phytochemical Analysis of Waltheria Indica (Velvet Leaf)}

Phytochemical analysis of the plant material was carried out in the laboratory to identify the constituents of Alkaloids, Tanins, Saponins, Flavonoids and Phenols using the methods described by Trease and Evans (1989) and Sofowora (1993).

\subsection{Sterilization of Soil}

Sandy loam soils were collected from bank of River Benue which was sieved to remove gravels, stones and plants debris with a $2 \mathrm{~mm}$ mesh sieve. The soil was poured into a metal drum and pasteurized for four (4) hours at $60^{\circ} \mathrm{C}$ with regular turning at 15minutes interval (Gautan and Goswami, 2007).

\subsection{Source and Preparation of Waltheria Indica Leaf Powder}

Fresh leaves of $W$. indica (Velvet leaf) was sourced around Teaching and Research Farm of the Department of Crop Protection, Modibbo Adama University of Technology, Yola and shed-dried on large polythene. The plant material was then ground into powder using pestle and mortar and was stored in air tight container.

\subsection{Incorporation of W. Indica Powder and Experimental Design}

Four (4 kg) of the sterilized soil that was allowed to cure for two (2) weeks contained in $20 \mathrm{~cm}$ diameter perforated plastic pots were separately mixed with $W$. Indica leaf powder at $50 \mathrm{~g} / \mathrm{pot}, 40 \mathrm{k} / \mathrm{pot}, 30 \mathrm{~g} / \mathrm{pot}$ and $0 \mathrm{~g} / \mathrm{pot}$. This was done two (2) weeks prior to planting to allow decomposition of the powder. The layout was Complete Randomized Design (CRD) with four treatments replicated three times using a total twelve (12) pots.

\subsection{Planting of Okra Seeds}

Okra seeds (Klemson spineless variety) were planted at the rate of two seeds per pots and thinned down to one plant per pot. Agronomic practices like weeding irrigation were carried out as required.

\subsection{Extraction and Inoculation of Meloidogyne Javanica}

The inoculum for this experiment were second stage juveniles $\left(\mathrm{j}_{2}\right)$ M. javanica extracted from pure culture on infested roots. The extraction was done using the methods described Whitehead and Hemming (1965). The inoculation was done by removing soil from the root zones to expose the roots and about 1000 juveniles $\left(\mathrm{J}_{2}\right)$ of $M$. javanica were dispensed into root zones of the Okra seedlings. One week after sowing using a 10ml syringe.

\subsection{Data Collection}

Data were collected on plant height $(\mathrm{cm})$, number of leaves, number of fruits per plant, fruit weight (g), fresh shoot weight (g) and dry shoot weight (g), fresh and dry root weight (g), galling index and final nematode population. All data were subjected to the analysis of variance (ANOVA) and means were separated using Duncan's Multiple Range Test (DMRT) at 5\% level of probability. Analysis of data was done using SAS Version 2001.

\section{Results and Discussion}

\subsection{Mean Plant Height (cm)}

The results of the experiments are presented in Table 1-2. Data on plant height showed that plants treated with $W$. indica powder gave the tallest plants. The significantly taller plants were observed in Okra treated with $50 \mathrm{~g}$ of $W$. indica, followed by $30 \mathrm{~g}$ treated plants and least plant height was shown in the control. This may be due to the decomposition of the $W$. indica powder and slow release of the phytochemicals (Alkaloids, Tanins, Saponins, Flavonoids and Phenols) (Table 1) and nutrients. This result is in agreement with those of Oyeke et al., (2014) who reported that application of Hyptis Suaveolens as soil amendment reduced the pathogenicity of $M$. javanica and improved the growth parameters of African Yam Beam Sphenostylis stenocarpa. The least plant height was observed in the control plants which is an indication that the nematodes deprived the plants of available nutrients which resulted in their poor growth. Khalid (2013) reported that common symptoms of infestation with root-knot nematodes are stunting, yellowing and wilting, but the major symptoms is gall formation in the plant roots.

\subsection{Mean Number of Leaves}

Mean number of leaves results indicated there was significant difference between the treated and untreated okra plants (Table 2). Plant treated with $50 \mathrm{~g}$ of $W$. indica powder had the highest number of leaves. This was due to ability of $W$. indicapowder to suppressed nematodes as a result of phytochemicals (Table 1) and subsequent release of nutrients that translated into increase number of leaves. The $40 \mathrm{~g}$ and $30 \mathrm{~g}$ of $W$. indica treated plants had a smaller number of leaves were in the untreated control plant (Table 2). This agrees with the finding of Mohammed and Umar (2012) who reported 
that there was significant increase in plant height and number of leaves of okra plants treated with garlic, lemon grass, onion and Tridax than the untreated control.

\begin{tabular}{|c|c|}
\hline Components & Qualitative \\
\hline Tanins & + \\
\hline Saponins & + \\
\hline Flavonoids & + \\
\hline Alkaloids & + \\
\hline Phenols & - \\
\hline Glycosides & - \\
\hline Steroids & + \\
\hline
\end{tabular}

Table 1: Phytochemical Composition of Waltheria indica

Key: + = Slightly present, - = Absent

\subsection{Mean Fresh and Dry Shoot Weight}

Fresh and dry shoot weight results showed that treated plants had the highest mean fresh shoot and dry weight and the least in the control plants (Table 2). This may attribute to ability of the powder that inhibited the M. javanica juveniles from attacking the roots, thereby allowing the roots to translocate water and nutrients to the upper parts of the plants. The result of this study corroborates with those of Sajid et al. (2011) who reported that plant extracts of neem applied as root treatment improved shoot weight of tomato grown on $M$. incognita infested soil. The control plants on the other hand recorded lower fresh and dry shoot weight (Table 2) which resulted in stunted growth as a result of plant parasitic nematode infestation.

\subsection{Mean Fresh and Dry Shoot Weight}

The results of mean fresh and dry root weight indicated that the control had the highest mean fresh and dry root weight (Table 2). This could have happened because of the presence of galls which were caused by nematode feeding on the roots.Ojo and Umar (2013) in their studies on the effect of two botanicals, oil palm fibre and cocoa bean test in the control of root-knot nematode on tomato revealed that control plants recorded the lowest growth rates, high galling due to nematode activity at root zone resulting in giant cell formation, high population of nematode because the nematodes larvae were able to penetrate roots freely and reproduce without any inhibition. Gall formation is a diagnostic symptom of root-knot nematode infestation (HAL, 2014). Lower fresh and dry root weight were observed in the treated plants (Table 2). However, the least mean fresh and dry weight were observed in $50 \mathrm{~g} \mathrm{~W}$. indica treated plants this was as a result of few galls on the roots of the plants which signifies that $50 \mathrm{~g} \mathrm{~W}$. indica powder was more effective than the other treatments.

\begin{tabular}{|c|c|c|c|c|c|c|}
\hline Treatments (g) & PH (cm) & NL & FSW $(g)$ & DSW (g) & FRW (g) & DRW (g) \\
\hline 30 & $27.67^{\mathrm{ab}}$ & $8.00^{\mathrm{b}}$ & $34.48^{\mathrm{b}}$ & $6.18^{\mathrm{b}}$ & $3.67^{\mathrm{b}}$ & $1.32^{\mathrm{b}}$ \\
\hline 40 & $28.36^{\mathrm{ab}}$ & $8.00^{\mathrm{b}}$ & $39.64^{\mathrm{b}}$ & $6.76^{\mathrm{b}}$ & $3.65^{\mathrm{b}}$ & $1.32^{\mathrm{b}}$ \\
\hline 50 & $32.50^{\mathrm{a}}$ & $10.00^{\mathrm{a}}$ & $50.24^{\mathrm{a}}$ & $8.88^{\mathrm{a}}$ & $2.32^{\mathrm{c}}$ & $0.71^{\mathrm{c}}$ \\
\hline Control & $18.44^{\mathrm{c}}$ & $7.00^{\mathrm{c}}$ & $17.03^{\mathrm{c}}$ & $3.02^{\mathrm{c}}$ & $4.55^{\mathrm{a}}$ & $2.15^{\mathrm{a}}$ \\
\hline S.E & 5.89 & 3.17 & 12.79 & 0.24 & 0.06 & 0.006 \\
\hline
\end{tabular}

Table 2: Effect of Different Levels of W. Indica Powder on Growth Parameter of Okra Plant Infested with

M. Javanica Mean in the Same Column Followed by the Same Letter Are Not

Significantly Different According to Duncan's New Multiple Range Test at $P \leq 0.05$

Key: $\quad P H=$ Plant Height, $N L=$ Number of Leaves, FSW = Fresh Shoot Weight,

DSW = Dry Shoot Weight, FRW = Fresh Root Weight, DRW = Dry Root Weight; S. E. = Standard Error

\subsection{Mean Fruit Weight}

Fruit weight results revealed that plants treated with $50 \mathrm{~g} W$. indica powder were higher than the rest of the treatments $(\mathrm{P} \leq 0.05)$ (Table 2$)$. The mean fruit weight increased as quantity of $W$. indicapowder increased, the control plants that received no powder recorded the lowest mean fruit weight. This suggests that $W$. indicasuppressed the activities of root-knot nematode and that resulted in higher yield weight of Okra than the untreated (control). In a similar studies Onyeke et al., (2014) reported the presence of certain phytochemicals (Terpenoids, Saponins, Tanins, Phenols, Flavonoids, Alkaloids, Resins, Glycosides and volatile oil) in the leaves of Hyptis suaveolens could be responsible for the reduction in the $M$. javanica population and reproduction on African Yam Bean.

\subsection{Mean Number of Fruits}

Result on mean number of fruits indicated the presence significant difference between the treated plants and the untreated plant (Table 2). Plants treated with $50 \mathrm{~g}$ of $W$. indicapowder had the highest number of fruits which may not be unconnected with the decomposition of the $W$. indicapowder which help in nematodes suppression and promote the performance of the plant to produce more fruits. This is in line with studies of Khalil (2014) which stated that the composition of products from soil amendment are directly toxic to plant nematodes and manipulation of soil amendment initiates a cascade of events favoring the build-up of bacteria, nematodes trapping fungi and other soil antagonist that destroy parasitic nematodes. In this study, the untreated (control) plant had least number of fruits due to nematode 
activity at root zone, which affected the performance of the roots which resulted in low yield. This agreed with the finding of Olabiyi (2008) who reported that $M$. incognita suppressed the growth and yield of tomato.

\begin{tabular}{|c|c|c|c|c|}
\hline Treatments (g) & NF & FW (g) & GI & NP \\
\hline 30 & $12.00^{\mathrm{b}}$ & $8.69^{\mathrm{b}}$ & $4.00^{\mathrm{b}}$ & $170.00^{\mathrm{b}}$ \\
\hline 40 & $13.00^{\mathrm{b}}$ & $8.81^{\mathrm{b}}$ & $3.00^{\mathrm{b}}$ & $117.00^{\mathrm{c}}$ \\
\hline 50 & $15.00^{\mathrm{a}}$ & $12.10^{\mathrm{a}}$ & $2.00^{\mathrm{c}}$ & $87.00^{\mathrm{d}}$ \\
\hline Control & $6.00^{\mathrm{c}}$ & $4.67^{\mathrm{c}}$ & $5.00^{\mathrm{c}}$ & $1500.00^{\mathrm{a}}$ \\
\hline S.E & 0.31 & 0.33 & 0.14 & 23.89 \\
\hline \multicolumn{4}{|}{ Table 3: Effect of Different Levels of Waltheria Indica Powder on Yield and } \\
Nematode Parameter on Okra Plant Infested with M. Javanica \\
Key: NF = Number of Fruit, FW = Fruit Weight, GI = Gall Index, \\
NP = Nematode Population, SE = Standard Error of Mean
\end{tabular}

\subsection{Mean Galling Index}

The untreated control plants recorded the highest mean galling index (Table 3). This was due to lack of $W$. indica powder on the roots of the control plant which served as a deterrent. The nematodes were able to penetrate the plant roots and feed freely and produced all which lead to formation of higher gall index in the control. Similar observation was made by Umar (2009) where he recorded highest gall index of 5.0 in untreated cowpea in his studies of effect of locust bean leaves and bark on the control of $M$. incognita on cowpea.

The least galling index was observed in plants treated with $50 \mathrm{~g} \mathrm{~W}$. indica powder followed by $40 \mathrm{~g}$ of the powder. This was due to the effectiveness of $W$. indica powder in inhibiting nematodes activity in the roots of okra and the phytochemicals present in the powder (Table 3 ).

\subsection{Mean Final Nematode Population}

The results on final nematode population revealed that the untreated plants recorded highest nematodes population (Table 3). This could be due to non-incorporation of $W$. indica powder which resulted in nematodes being free to penetrate, feed and reproduce within the roots of the control plants. This is in line with studies of Wondimench et al., (2013) who reported that application of botanicals reduced the formation of galls in tomato roots, number of eggs and final nematode density in soil infested with $M$. incognita. Final nematode population was however lower in the treated plants which could be attributed to the bioactivities of $W$. indica powder which increased organic matter, nitrogen and possibly other nutrients and the phytochemicals (Table 1) released from the powder. Soil amendment with rice husk, saw dust cow urine, cow dung significantly reduces the reproductive factor and root-knot nematode $M$. incognita population and increase growth parameters of tomato (Nagaraju et al., 2010).

\section{Conclusion}

In conclusion, Waltheria indicaleaf (Velvet leaf) powder at different levels (50, 40 and 30g) were able to control $M$. javanica on okra in the screenhouse, among the treatment'sapplication of $50 \mathrm{~g}$ was the most effective. Therefore, evident by findings of this study, $W$. indicaleaf powder has nematicidal potentials. Hence, we recommend that further field studies should be tried under natural condition to ascertain the effectiveness of the plant.

\section{References}

i. Adeboye, O. C. and C. O. Oputa (1996). Effect of galex on growth and fruit nutrient composition of okra (Abelmoschus esculentus L. Moench). Ife Journal of Agriculture, 18(1\&2), 19.

ii. Andras, C. D., Simandi, B., Orsi, F., Lambrou, C., Tatla, D. M. and C. Panayiotou (2005). Super critical carbon dioxide extraction of okra (Hibiscus esculentus L.) seeds. Journal of Science of Food and Agriculture, 85, 1415-9.

iii. Bashir, A. B. (2000). Water quality and outbreak of diseases in Yola, Adamawa State, M.Sc. Thesis submitted to the Department of Geography, Federal University of Technology, Yola (Unpublished) Thesis 120p.

iv. Farrooq, A., Umer, R., Muhammad A. and N. Muhammad (2010). Okra (Hibiscus esculentus) seed oil for biodiesel production. Applied Energy, 87(3), 779-785.

v. Iyewere, S. (2012). Fruit of the week: Okra Eden Lifestyle.

vi. Mohammed, B. A. and I. Umar (2012). Evaluation of some of some plant materials for the control of root-knot nematode (Meloidogyne javanica) on okra in Yola, Adamawa State, Nigeria.New Clues in Sciences, 2(2012), 20-27.

vii. Nagaraju, M. Karemegam, N. and Kadalmani, B. (2010). Eco-friendly Management of Root-knot nematode Meloidogyne incognita using organic amendments on Tomato. International Journal of Research Pharm. Sci.,1 (1), 530-532.

viii. Ojo, G. T. and Umar, I. (2013). Evaluation of some Botanicals on Root Knot Nematode (Melodogyne javanica) in Tomato (Lycopersicon esculentum mill) In Yola Adamawa State, Nigeria. Biological forum-An International Journal,5(2): 31-36.

ix. Olabiyi, T.I. (2008). Pathogenicity study and nematotoxic properties of some plant extracts on the root knot nematodes pest of tomato, Lycopersicon esculentum (L.) Mill. Plant Pathology Journal,7(1):45-49. 
X. Onyeke, C. C., Ajuziogu, G. C., Osayi, E. E. Nwani, D. C. and Odo, E. G. (2014). Efficacy of Soil Amendment with Leaf Powder of Hyptis suaveoens (L.) Poit in the Control of Meloidogyne javanica (Treub) Chitwood on African Yam bean Spenostylis stenocarpa (Hochst Ex A. Rich) Harms. Plant Pathology Journal, 13(2), 112-119.

xi. Sajid, A.K, JAved, N., Khan, M.A., Haq, I.U., and Safdar, A. (2011). Use of plant extracts as bare root treatment for the management of Meloidogyne incognita.PakistanJournal of Phytopathology,23(1):9-13.

xii. Saufiuddin, S., Sheila, S. and Shweta, S. (2011). Pathogenicity of root-knot nematode, Meloidogyne incognita and root-knot fungus, Rhizoctonia solani on okra (Abelmoschus esculentus L.). E-Journal of Science and Technology, $3(6)$.

xiii. Schippers, R. R. (2000). African indigenous vegetables: An overview of the cultivated species, Natural Resource Institute. E. V. Technical Centre of Agriculture and Rural Co-operation, Chatham, 214.

xiv. Siddiqui, Z.A (2004). Effects of plant growth promotion bacteria and composed organic fertilizer on the reproduction of Meloidogyne incognita and tomato growth. Bioresource Technology, 95:223-227.

xv. Sofowara, A. (1993). Medicinal Plants and Traditional Medicine in Africa. Spectrum Books Ltd. Ibadan, Nigeria P. 289.

xvi. Trease, G. E. and Evans, W. C. (1989). Pharmacognosy $11^{\text {th }}$ Edition. Brailiare Tindal and Macmillan Publishers, London

xvii. Umar, I. (2009). Effects of locust bean leaves and bark on the control of Meloidogyne incognita on cowpea (Vigna unguiculata L. Walp). Nigerian Journal of Tropical Agriculture, 11: 16-20.

xviii. Vermis, J. C. and P. A. Roberts (1996). Relationships between Meloidogyne incognita resistance gene in Lycopersicon peruvianm differentiated by heat sensitivity and nematode virulence. Theoretical Applied Genesis, 93: 950-959.

xix. Walker, G. E. (2004). Effects of Meloidogyne javanica and organic amendments, inorganic fertilizer and nematicides on carrot growth and nematode abundance.Nematologia Mediterranea, 32: 181-188.

xx. Whitehead, A.G. and J.R. Hemming (1965). A comparison of some quantitative method of extracting small vermiform nematodes from soil. Annals of Applied Biology, 55: 25-38.

xxi. Whitehead, A.G. and J.R. Hemming (1965). A comparison of some quantitative method of extracting small vermiform nematodes from soil. Annals of Applied Biology, 55: 25-38.

xxii. Wondimeneh, T. Sakhuja, P. K. and Tadele, T. (2013). Root-Knot nematode (Meloidogyne incognita) management using botanicals in tomato (Lycopersicon esculentum). Academia Journal of Agricultural Research,1(1): 009-016.

xxiii. Wondimeneh, T. Sakhuja, P. K. and Tadele, T. (2013). Root-Knot nematode (Meloidogyne incognita) management using botanicals in tomato (Lycopersicon esculentum). Academia Journal of Agricultural Research,1(1): 009-016. 